\title{
PENGARUH GAYA KEPEMIMPINAN TRANSFORMASIONAL, BUDAYA ORGANISASI, PROGAM KESELAMATAN DAN KESEHATAN KERJA TERHADAP KEPUASAN KERJA KARYAWAN
}

\author{
I Gusti Ngurah Aritama Negara ${ }^{1}$ \\ I Gusti Ayu Dewi Adnyani² \\ ${ }^{1,2}$ Fakultas Ekonomi dan Bisnis Universitas Udayana, \\ Denpasar, Bali-Indonesia \\ email: ignaritamanegara14@yahoo.com
}

\begin{abstract}
ABSTRAK
Perkembangan produksi Air Minum Dalam Kemasan (AMDK) di Indonesia memperlihatkan peningkatan yang cukup signifikan. Saat ini terdapat lebih dari 500 perusahaan AMDK dimana sebagian besar (60\%) merupakan pemain berskala sedang kecil yang wilayah pemasarannya bersifat lokal. Tujuan penelitian ini adalah untuk mengetahui pengaruh gaya kepemimpinan transformasional, budaya organisasi, dan program keselamatan dan kesehatan kerja terhadap kepuasan kerja. Penelitian ini dilakukan pada PT. Tirta Investama Mambal Kabupaten Badung. Jumlah populasi yang diambil sebanyak 238 orang, dalam penelitian ini metode penentuan sampel yang digunakan adalah proportionate stratified random sampling diambil sebanyak 70 orang. Pengumpulan data dilakukan melalui data primer berupa kuesioner dan wawancara. Teknik analisis yang dilakukan pada penelitian ini menggunakan metode regresi linier berganda. Berdasarkan hasil penelitian dapat disimpulkan gaya kepemimpinan transformasional, budaya organisasi, serta program keselamatan dan kesehatan kerja berpengaruh positif dan signifikan terhadap kepuasan kerja.
\end{abstract}

Kata Kunci: gaya kepemimpinan transformasional, budaya orgaisasi, program keselamatan dan kesehatan kerja, kepuasan kerja.

\begin{abstract}
The research objectives were to analyze: (1) to determine the effect of transformational leadership on employee communication at the Bali Regional Development Bank; (2). To analyze the effect of transformational leadership on employee organizational commitment at the Bali Regional Development Bank; (3). To analyze the effect of communication on the organizational commitment of Bali Regional Development Bank employees; (4). To explain the role of communication in mediating transformational leadership to the organizational commitment of Bali Regional Development Bank employees. The sample was determined as many as 51 people with saturated sampling techniques. Data collection was carried out by spreading interviews, observations and questionnaires directly to employees of the BPD Bank and analyzed using descriptive statistics calculated average and descriptive statistics in the form of a classic assumption test and path analysis. The results of the data analysis show that the transformational leadership variable has a positive effect on employee communication, the transformational leadership variable has a positive effect on the organizational commitment employees, the communication variable has a positive effect on the organizational commitment of employees, and the communication variable has a positive effect on mediate the effect of transformational leadership on organizational commitment.
\end{abstract}

Keywords: transformational leadership, communication, organizational commitment 


\section{PENDAHULUAN}

Perkembangan produksi Air Minum Dalam Kemasan (AMDK) di Indonesia memperlihatkan peningkatan yang cukup signifikan. Saat ini terdapat lebih dari 500 perusahaan AMDK dimana sebagian besar (60\%) merupakan pemain berskala sedang kecil yang wilayah pemasarannya bersifat lokal. Namun demikian, dilihat dari pangsa pasarnya, industri AMDK dikuasai pemain-pemain berskala besar dengan merek yang sudah dikenal masyarakat. Sampai saat ini, Danone Group dengan merk Aqua masih mendominasi pangsa pasar.

Rizi (2013) menyatakan salah satu faktor funda mental yang mempengaruhi kepuasan kerja karyawan adalah gaya kepemimpinan. Gaya kepemimpinan dianggap sebagai salah satu faktor penentu yang paling penting dari kepuasan kerja karyawan yang secara ekstensif mempengaruhi motivasi dan dedikasi karyawan. Menurut Supardi \& Anwar (2011:76) efektivitas gaya kepemimpinan menjadi hal yang penting bagi tercapainya tujuan perusahaan, karena gaya kepemimpinan yang efektif dapat memberikan pengarahan dengan baik terhadap semua pekerjaan dalam mencapai tujuan-tujuan organisasi. Gaya kepemimpinan adalah suatu cara pemimpin untuk mempengaruhi bawahannya. Menurut Maqsood (2013) gaya kepemimpinan adalah prosedur untuk mempengaruhi orang-orang untuk mencapai hasil yang diinginkan. Karyawan adalah aset organisasi sehingga pimpinan harus memberikan kesempatan kepada karyawan mereka untuk berinovasi untuk menjadi organisasi yang sukses dan inovatif. Burn membedakan antara gaya kepemimpinan transformasional dan kepemimpinan transaksional. Menurut Yukl (2010:290) gaya kepemimpinan transformasional mempengaruhi nilai-nilai moral dari pengikutnya dalam upaya untuk memotivasi kekuatan dan sumber daya mereka untuk mengefektifkan organisasi, sedangkan gaya kepemimpinan transaksional menurut Yukl (2010:290) adalah kepemimpinan yang melakukan transaksi dalam memotivasi para pengikut dengan menyerukan kepentingan pribadi mereka.

Kepemimpinan transformasional menunjukkan seorang pemimpin yang mampu mengubah nilai, kebutuhan, aspirasi, prioritas pengikut dan juga memotivasi pengikut mereka untuk melebihi harapan. Lebih jelasnya gaya kepemimpinan transformasional adalah kemampuan yang dimiliki oleh para pemimpin untuk mempengaruhi bawahannya untuk meningkatkan kesadaran tentang pentingnya hasil kerja, memprioritaskan pentingnya kelompok, dan untuk meningkatkan kebutuhan bawahan mereka ke tingkat yang lebih tinggi untuk mencapai kualitas hidup yang lebih baik (Yukl, 2010:292). Gaya kepemimpinan transformasional bisa membawa perubahan signifikan yang membawa pengaruh terhadap kepuasan kerja karyawan (Thamrin, 2012:566).

Hasil penelitian Bushra (2011) menemukan gaya kepemimpinan transformasional berpengaruh signifikan terhadap kepuasan kerja karyawan. Sunadji (2013) dalam penelitiannya menemukan budaya organisasi berpengaruh signifikan terhadap kepuasan kerja karyawan. Hasil penelitian Mamesah (2009) menemukan bahwa dari sisi gaya kepemimpinan, hasil penelitian menunjukkan bahwa gaya kepemimpinan transformasional berpengaruh signifikan terhadap kepuasan kerja dan berpengaruh signifikan terhadap kinerja karyawan melalui kepuasan kerja. Kontribusi kreativitas dari karyawan sangat penting artinya dalam 
terobosan inovasi yang dapat dilakukan perusahaan. Pimpinan haruslah mampu menciptakan kondisi yang kondusif melalui gaya kepemimpinan transformasional untuk mencari sesuatu yang baru bukan hanya berorientasi pada pemecahan masalah. Pemimpin haruslah memilih dan mempertahankan karyawan yang kreatif dan mandiri serta memberikan peluang bagi mereka untuk berinovasi. Sedangkan di perusahaan tersebut atasan kurang mendengarkan masukan atau gagasan baru dari karyawan lainnya.

Persaingan yang ketat, salah satu strategi yang ditempuh yakni dengan melakukan perekayasaan atau pembentukan budaya organisasi (corporate culture) yang kuat. Budaya organisasi (organizational culture) adalah sebuah sistem makna bersama yang dianut oleh para anggota yang membedakan suatu organisasi dari organisasi-organisasi lainnya (Robbins \& Timothy, 2008:256). Menurut Syauta (2012) budaya organisasia dalah pola asumsi dasar yang diciptakan, ditemukan, atau dikembangkan oleh kelompok tertentu ketika mereka mengadaptasi diri dengan masalah-masalah eksternal dan internal sehingga mereka dapat bekerja dengan baik. MacIntosh (2010) menyatakan bahwa efek dari pelaksanaan budaya organisasi adalah terhadap sikap dan perilaku individu serta kinerja perusahaan secara keseluruhan sebagai fenomena yang menarik dari studinya. Hal ini menunjukkan bahwa budaya organisasi bertindak sebagai sistem kontrol sosial dan dapat mempengaruhi sikap dan perilaku karyawan melalui nilai-nilai dan keyakinan yang dijalankan di sebuah perusahaan.

Mehr (2012) melalui studi ilmiah menemukan adanya hubungan yang signifikan antara budaya organisasi dengan kepuasan kerja, jika karyawan menunjukkan tingkat yang lebih tinggi untuk identitas budaya organisasi, maka tingkat kepuasan kerja juga akan lebih tinggi. Penelitian Rizondra (2013) diketahui bahwa terdapat pengaruh signifikan positif antara budaya organisasi dengan kepuasan kerja, jika semakin tinggi budaya organisasi yang ada pada pegawai maka akan semakin tinggi tingkat kepuasan kerja yang dirasakan oleh pegawai, sebaliknya jika budaya organisasi pegawai rendah dalam bekerja maka semakin turun juga kepuasan yang akan dimiliki dalam bekerja. Hasil penelitian menemukan bahwa budaya organisasi berpengaruh positif dan signifikan terhadap kepuasan kerja.

Kemajuan ilmu pengetahuan khususnya di bidang teknologi, telah mengakibatkan turunnya persentase penggunaan tenaga manusia dalam bidang industri. Ditemukannya mesin-mesin serta penggunaannya di dalam proses produksi telah mengurangi fungsi tenaga manusia dalam bekerja. Penggunaan mesin-mesin dalam proses produksi akan meningkatkan resiko dan bahaya kerja, untuk itu diperlukan usaha-usaha untuk melindungi keselamatan dan kesehatan kerja karyawan dalam menjalankan pekerjaannya. Ketentuan mengenai keselamatan kerja dan kesehatan kerja diatur dalam Undang-Undang RI No 5 Tahun 2015 dinyatakan bahwa setiap pekerja atau buruh mempunyai hak untuk memperoleh perlindungan atas keselamatan dan kesehatan kerja, moral, dan kesusilaan dan perlakuan yang sesuai dengan harkat dan martabat serta nilai-nilai agama. Peraturan ini menjelaskan bahwa dengan sistem produksi yang makin modern sehingga peralatan dan bahan-bahan yang dipergunakan juga semakin membahayakan, maka menjadi kewajiban bagi perusahaan untuk menjamin 
keselamatan kepada karyawan yang mengalami kecelakaan di dalam menjalankan pekerjaannya. Tawiah (2011) menyebutkan tujuan keselamatan dan kesehatan adalah: pemeliharaan fisik, mental dan kesejahteraan sosial pekerja di semua pekerjaan, mencegah terjadinya kecelakaan kerja serta memberikan perlindungan bagi pekerja terhadap risiko yang merugikan kesehatannya.

Perencanaan keselamatan dan kesehatan kerja pada dasarnya harus mengimbangi biaya pencegahan dengan manfaat yang diperoleh dari upaya tersebut. Manfaat yang diperoleh adalah: biaya yang dapat diselamatkan dan meningkatkan produktivitas sehubungan dengan langkah-langkah pencegahan. Kondisi ini akan berpengaruh terhadap meningkatnya kepuasan kerja karyawan (Sedarmayanti, 2011:211). Pernyataan ini dipertegas dengan kajian empirik hasil penelitian sebelumnya. Kurniawan (2011) menemukan bahwa program keselamatan dan kesehatan kerja berpengaruh positif terhadap kepuasan kerja karyawan. Hasil penelitian Sageer (2012) menunjukkan bahwa kepuasan kerja karyawan di identifikasikan dipengaruhi oleh program keselamatan dan kesehatan kerja.

Budaya organisasi PT. Tirta Investama Mambal, Kabupaten Badung terdiri atas unsur nilai-nilai dasar yang dapat dilihat (observable) dan yang tidak kelihatan (unobservable). Pada level observable, budaya organisasi mencakup beberapa aspek organisasi seperti arsitektur, logo perusahaan, peraturan, pola perilaku, bahasa, dan cara berpakaian, sedangkan pada level unobservable, budaya organisasi mencakup norma-norma, keyakinan/kepercayaan, asumsi-asumsi para anggota organisasi untuk mengelola masalah, dan keadaan-keadaan di sekitarnya. Untuk menerapkan suatu budaya organisasi bukanlah suatu pekerjaan yang mudah karena pada dasarnya karyawan PT. Tirta Investama Mambal, Kabupaten Badung mempunyai karakteristik tingkah laku yang berbeda sesuai dengan tingkat kebutuhannya.

Budaya organisasi difokuskan dalam rangka menjabarkan tugas sehari-hari untuk upaya pencapaian visi PT. Tirta Investama yaitu senantiasa berupaya untuk menjadi penyedia layanan logistik yang sangat handal, sehingga mampu memberikan layanan terbaik bagi konsumen serta tumbuh dan berkembang sesuai dengan konsep bisnis yang sehat. Adapun nilai-nilai budaya organisasi pada PT. Tirta Investama adalah : 1) layanan yang handal, 2) cepat dan tepat memberikan pelayanan,3) perbaikan kualitas pelayanan yang berkesinambungan, 4) ikatan kerjasama di antara seluruh jajaran, dan 5) bertanggung jawab kepada pihak yang berkepentingan.

Ditinjau dari lima nilai budaya yang terdapat di perusahaan, dua diantaranya yakni cepat dan tepat memberikan pelayanan, dan ikatan kerjasama di antara seluruh jajaran belum dapat dijalankan dengan baik. Berkaitan dengan cepat dan tepat memberikan pelayanan, maka diketahui berdasarkan pengamatan penulis beberapa karyawan kurang maksimal dalam bekerja sehingga masih lambat dalam memberikan pelayanan dan ada kesalahan saat merealisasikan pengiriman barang. Ikatan kerjasama di antara seluruh jajaran dinilai masih kurang, hal ini terlihat dari keengganan beberapa orang karyawan bekerjasama dengan karyawan lainnya karena tidak ada kecocokan pribadi yang disertai dengan persaingan kerja yang 
tinggi antar karyawan. Keadaan seperti ini apalagi disertai dengan kurangnya pengawasan menyebabkan kinerja yang dicapai kurang baik.

PT. Tirta Investama Mambal, Kabupaten Badung juga memperhatikan pentingnya pelaksanaan program keselamatan dan kesehatan kerja. Program keselamatan kerja dilaksanakan dengan: 1) Menyediakan alat-alat pengamanan untuk melindungi karyawan pada saat bekerja, seperti alat pemadam kebakaran dan tangga darurat serta kamera (CCTV) tersembunyi untuk mengetahui kejadiankejadian janggal yang terjadi di perusahaan, 2) Pemeriksaan perlengkapan dan peralatan sebelum karyawan bekerja, 3) Peralatan dan fasilitas teknik (mechanical electrical) seperti komputer, genzet, lift, pipa air dan kabel dirawat agar tidak rusak dan menghindari dari gangguan, dan 4) Tersedianya fasilitas P3K yang bertujuan untuk mempermudah karyawan yang memerlukan pengobatan jika terjadi kecelakaan ringan di tempat kerja. Program kesehatan kerja meliputi: 1)Adanya jaminan asuransi kesehatan kerja untuk karyawan yang membuat mereka merasa tenang dan nyaman dalam melakukan pekerjaan, dan 2)Semua karyawan diberikan asuransi kesehatan dimana pihak perusahaan telah melakukan kerjasama dengan beberapa rumah sakit dan karyawan pun dapat mengunjungi rumah sakit tersebut bila terjadi keluhan terhadap kesehatan.

Beberapa keluhan karyawan terjadi berkaitan dengan program keselamatan dan kesehatan kerja di PT. Tirta Investama Mambal, Kabupaten Badung. Kurang memadainya alat-alat pengamanan yang disediakan oleh perusahaan untuk melindungi karyawan jika terjadi kecelakaan kerja seperti alat pemadam kebakaran dan kamera (CCTV) yang tidak berfungsi baik sehingga kurang menjamin keselamatan karyawan.Kondisi beberapa peralatan dan fasilitas teknik yang kurang aman, seperti pipa air yang bocor, kabel yang rusak dan penempatannya yang tidak teratur sehingga dapat membahayakan karyawan. Ruang kerja karyawan khususnya pada bagian produksi tidak mempunyai ruang gerak yang memadai dalam melakukan aktivitas kerja,hal ini dapat dilihat dari kurang luasnya ruang kerja jika dibandingkan dengan peralatan yang ada. Tidak diberikan pemeriksaan kesehatan awal dan berkala bagi setiap karyawan padahal sudah merupakan aturan setiap perusahaan harus menyediakan itu. Hal ini menyebabkan karyawan tidak dapat menyelesaikan pekerjaannya dengan baik jika terganggu kesehatannya. Ruang kesehatan yang kurang memadai, sehingga jika karyawan mengalami gangguan kesehatan pada saat kerja maka karyawan dibantu rekannya akan berobat ke klinik atau rumah sakit untuk memeriksa masalah kesehatannya.

Sumber Daya Manusia (SDM) adalah faktor sentral dalam suatu organisasi. Apapun bentuk serta tujuannya, organisasi dibuat berdasarkan visi untuk kepentingan manusia dan dalam pelaksanaan misinya dikelola dan diurus oleh manusia. Jadi, manusia merupakan faktor strategis dalam semua kegiatan organisasi atau dengan kata lain manusia merupakan kekayaan (asset) yang paling utama yang dimiliki oleh suatu organisasi (Yuniarsih \& Suwatno, 2008:8) Manajemen sumber daya manusia dalam suatu organisasi menjadi hal yang penting karena dapat mengelola sumber daya manusia dalam usaha meningkatkan efektifitas dan efesiensi organisasi,dengan demikian sudah selayaknya karyawan diperlakukan secara layak dan adil sesuai dengan apa yang telah diberikannya 
kepada perusahaan, yang dapat berimplikasi kepada meningkatnya kepuasan kerja karyawan (Umar, 2011:38).

Kepuasan kerja (job satisfaction) merupakan variabel dependen yang utama yaitu suatu perasaan positif tentang pekerjaan seseorang yang merupakan hasil dari evaluasi karakteristiknya. Kepuasan kerja lebih menggambarkan sikap daripada perilaku (Robbins \& Timothy, 2008:18). Pentingnya kepuasan kerja karyawan dapat dilihat dari pengaruhnya terhadap komitmen dan loyalitas karyawan pada perusahaan. Kepuasan kerja karyawan yang tinggi akan meningkatkan produktivitas dan kualitas kerja karyawan sehingga akan mempengaruhi tingkat keuntungan perusahaan. Berdasarkan hal ini maka penting diperhatikan variabel-variabel yang berpengaruh terhadap kepuasan kerja karyawan. Masalah-masalah yang menyebabkan kepuasan kerja yaitu perkerjaan yang dilakukan, gaji, promosi, supervisi, serta lingkungan kerja dan rekan sekerja.

Kenyataan terjadi di lingkungan kerja, masih banyak karyawan yang merokok saat jam kerja sehingga pekerjaan menjadi terhambat. Adanya perhatian dan ditemui permasalahan berkaitan dengan gaya kepemimpinan transformasional, budaya organisasi, program keselamatan dan kesehatan kerja dalam usaha meningkatkan kepuasan kerja karyawan maka sangat layak dalam penelitian ini diteliti lebih jauh lagi pengaruh gaya kepemimpinan, budaya organisasi, program keselamatan dan kesehatan kerja terhadap kepuasan kerja karyawan di PT. Tirta Investama Mambal, Kabupaten Badung.

Kepemimpinan transformasional adalah gaya kepemimpinan yang mempunyai kekuatan untuk mempengaruhi bawahan dengan cara-cara tertentu. Dengan penerapan kepemimpinan transformasional bawahan akan merasa dipercaya, dihargai, loyal dan respek kepada pimpinannya. Pada akhirnya bawahan akan termotivasi untuk melakukan lebih dari yang diharapkan sehingga hasil yang dicapai lebih memuaskan (Yukl, 2010:224).

Pernyataan ini dipertegas secara empirik oleh beberapa hasil penelitian sebelumnya. Akmal (2015) menemukan bahwa kepuasan kerja karyawan dipengaruhi oleh variabel gaya kepemimpinan transformasional. Widyatama (2015) menemukan bahwa gaya kepemimpinan transformasional dan gaya kepemimpinan transaksional berpengaruh positif dan signifikan terhadap kepuasan kerja. Saputra (2012) dalam penelitiannya menemukan bahwa kondisi diskriptif gaya kepemimpinan transformasional dan kepuasan kerja karyawan adalah tergolong tinggi, terdapat pengaruh langsung dan signifikan antara gaya kepemimpinan transformasional terhadap kepuasan kerja karyawan. Wijanto (2013) menemukan bahwa variabel gaya kepemimpinan mempunyai pengaruh yang positif dan paling dominan terhadap kepuasan kerjakaryawan.

Berdasarkan telaah landasan teori yang ada, maka dapat disusun hipotesis sebagai berikut.

$\mathrm{H}_{1}$ : Gaya kepemimpinan transformasional berpengaruh positif terhadap kepusan kerja karyawan.

Mensiasati persaingan yang ketat, salah satu strategi yang ditempuh yakni dengan melakukan perekayasaan atau pembentukan budaya organisasi (corporate culture) yang kuat. Budaya organisasi (organizational culture) adalah sebuah sistem makna bersama yang dianut oleh para anggota yang membedakan suatu 
organisasi dari organisasi-organisasi lainnya. Budaya organisasi yang kuat akan meningkatkan kepuasan kerja karyawan (Purba, 2016).

Pernyataan ini dipertegas dengan kajian empirik dari beberapa hasil penelirian sebelumnya. Hasil penelitian Herawan (2015) menemukan bahwa budaya organisasi berpengaruh positif dan signifikan terhadap kepuasan kerja. Penelitian Purnama (2013) menunjukkan bahwa budaya organisasi yang kuat memberikan efek positif bagi peningkatan kepuasan kerja karyawan. Penelitian Steven (2016) menemukan bahwa berdasarkan hasil analisis data dari penelitian yang telah dilakukan dapat diketahui terdapat pengaruh yang signifikan dari budaya organisasi terhadap kepuasan kerja karyawan. Novita (2016) menemukan bahwa ada pengaruh positif antara budaya organisasi terhadap kepuasan kerja karyawan.

Berdasarkan telaah landasan teori yang ada, maka dapat disusun hipotesis sebagai berikut.

$\mathrm{H}_{2}$ : Budaya organisasi berpengaruh positif terhadap kepuasan kerjakaryawan.

Perencanaan keselamatan dan kesehatan kerja pada dasarnya harus mengimbangi biaya pencegahan dengan manfaat yang diperoleh dari upaya tersebut. Manfaat yang diperoleh adalah: biaya yang dapat diselamatkan dan meningkatkan produktivitas sehubungan dengan langkah-langkah pencegahan. Kondisi ini akan berpengaruh terhadap meningkatnya kepuasan kerja karyawan (Kahfirardi, 2017).

Pernyataan ini dipertegas dengan kajian empirik dari beberapa hasil penelirian sebelumnya. Maulana (2015) menemukan bahwa berdasarkan hasil analisis yang telah dilakukan diketahui kesehatan kerja dan keselamatan kerja memiliki pengaruh yang signifikan terhadap kepuasan kerja karyawan. Amalita (2015) dalam penelitiannya menemukan bahwa variabel dari Sistem Manajemen Keselamatan dan Kesehatan Kerja (SMK3) yang terdiri dari variabel komitmen dan kebijakan manajemen terhadap $\mathrm{K} 3$, perencanaan $\mathrm{K} 3$, implementasi $\mathrm{K}$ 3, pemeriksaan K3, dan tinjauan manajemen dan peningkatan SMK3 secara simultan bersama-sama mempunyai pengaruh signifikan terhadap kepuasan kerja karyawan.Hasil penelitian Yusnita (2012) menemukan adapengaruh yang signifikan antara program K3 terhadap kepuasan kerja karyawan.

Berdasarkan telaah landasan teori yang ada, maka dapat disusun hipotesis sebagai berikut.

$\mathrm{H}_{3}$ : Program keselamatan dan kesehatan kerja berpengaruh positif terhadap kepuasan kerja karyawan.

Model penelitian diperoleh berdasarkan rumusan hipotesis penelitian tersebut, bentuk model penelitian pada penelitian ini yang disajikan berikut. 


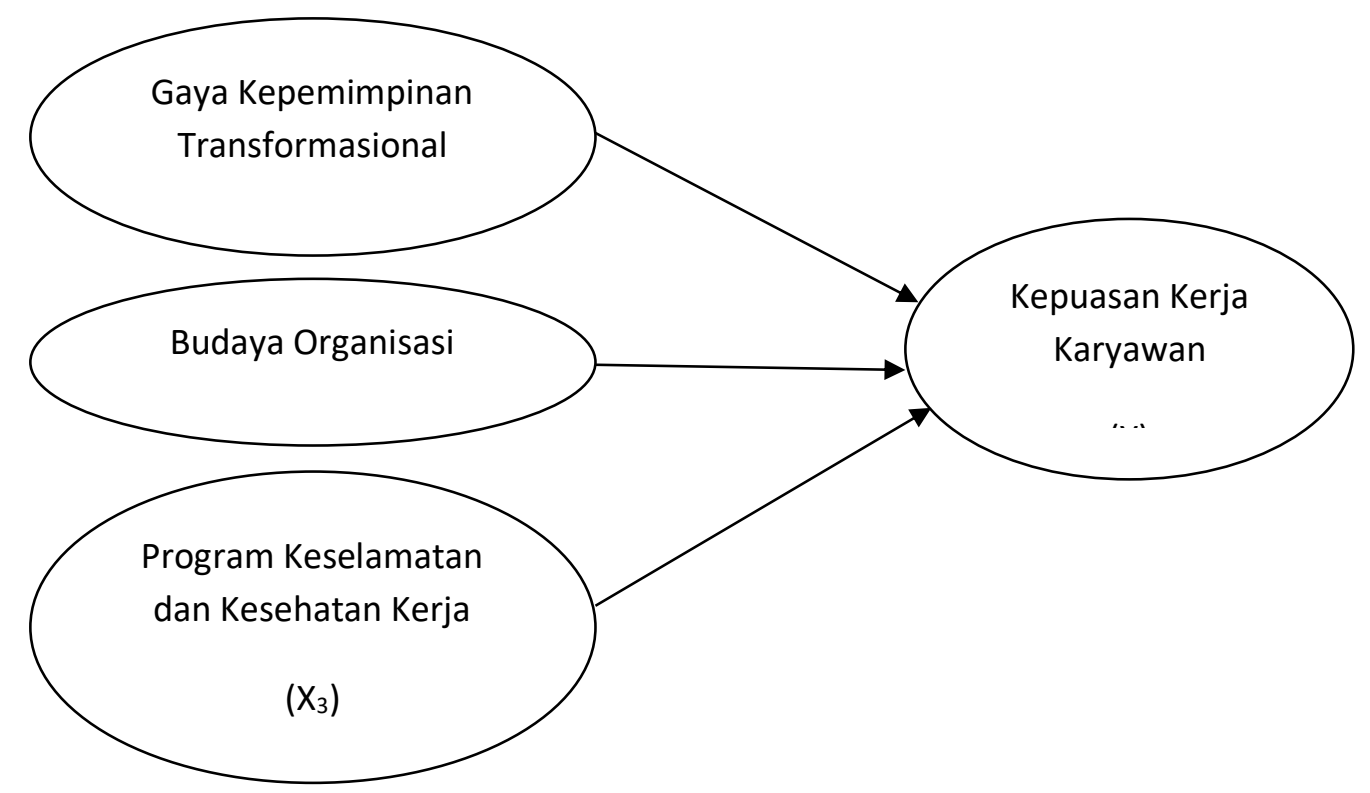

Gambar 1. Model Konseptual

$\mathrm{H}_{1} \quad$ : Yukl, 2010:224, Akmal (2015), Widyatama (2015), Saputra (2013), Wijanto (2013)

$\mathrm{H}_{2}$ : Purba (2016), Koko Herawan (2015), Purnama (2013), Steven Set Xaverius (2016), Novita Indraswari (2016)

$\mathrm{H}_{3} \quad$ : Kahfirardi Fajri (2017), Maulana (2015), Aulia Nur Amalita (2015), Yusnita (2012)

Sumber: Data diolah, 2020

\section{METODE PENELITIAN}

Penelitian ini bersifat asosiatif yang bertujuan untuk mengetahui pengaruh atau hubungan antara dua variabel atau lebih. Penelitian ini menganalisis hubungan gaya kepemimpinan transformasional, budaya organisasi, program keselamatan dan kesehatan kerja terhadap kepuasan kerja karyawan. Penelitian ini dilakukan pada pada PT. Tirta Investama, yang beralamat di Banjar Gumasih, Desa Mambal, Kecamatan Abiansemal, Kabupaten Badung.Adapun yang melatar belakangi pemilihan lokasi pada penelitian ini karena ditemukan masalah berkaitan dengan gaya kepemimpinan transformasional, budaya organisasi, program keselamatan dan kesehatan kerjadalam usaha meningkatkan kepuasan kerja karyawandi PT. Tirta Investama Mambal, Badung. Sebagai obyek dalam penelitian adalah bidang manajemen sumber daya manusia yaitu kepuasan kerja karyawan, gaya kepemimpinan transformasional, budaya organisasi, program keselamatan dan kesehatan kerja.

Variabel terikat dalam penelitian ini adalah kepuasan kerjakaryawan (Y). Sedangkan variabel bebas dalam penelitian ini adalah gaya kepemimpinan 
transformasional $\left(\mathrm{X}_{1}\right)$, budaya organisasi $\left(\mathrm{X}_{2}\right)$, program keselamatan dan kesehatan kerja $\left(\mathrm{X}_{3}\right)$.

Data kuantitatif dalam penelitian ini berupa jumlah karyawan, skor jawaban kuesioner kepuasan kerja karyawan, gaya kepemimpinan transformasional, budaya organisasi, program keselamatan dan kesehatan kerja. Sedangkan data kualitatif dalam penelitian ini berupa sejarah perusahaan, struktur organisasi dan deskripsi jabatan. Sumber primer yang digunakan dalam penelitian ini yaitu data yang dikumpulkan dan diamati dari PT. Tirta Investama Mambal, Badung serta memerlukan pengolahan lebih lanjut terhadap data tersebut. Data primer dalam penelitian ini yaitu pernyataan karyawan sebagai responden dalam pengisian kuesioner kepuasan kerja karyawan, gaya kepemimpinan transformasional, budaya organisasi, program keselamatan dan kesehatan kerja. Sedangkan sumber sekunder yang digunakan dalam penelitian ini yaitu data yang diperoleh dari dokumen-dokumen dari PT. Tirta Investama Mambal, Badung seperti jumlah karyawan,sejarah perusahaan, struktur organisasi dan deskripsi jabatan.

Populasi dalam penelitian ini adalah sebanyak 238 orang karyawan PT. Tirta Investama Mambal, Badung tahun 2016. Berkaitan dengan penentuan sampel, apabila subjek kurang dari 100, maka lebih baik diambil semua, sehingga penelitiannya merupakan penelitian populasi. Selanjutnya jika subjeknya besar, dapat diambil antara 10\%-15\% atau 20\%-25\% atau lebih (Riduwan dan Akdon, 2013:253-254). Metode pengambilan sampel dalam penelitian ini menggunakan proportionate stratified random sampling, adalah pengambilan sampel dari anggota populasi secara acak dan berstrata secara proporsional, dilakukan sampling ini apabila anggota populasinya heterogen (tidak sejenis) (Riduwan \& Sunarto, 2012:254). Dengan dasar pertimbangan keterbatasan biaya, waktu dan tenaga disamping karena jumlah populasi cukup banyak maka sampel penelitian ditentukan sebesar $25 \%$ dari jumlah populasi dari masing-masing jabatan/bagian.

Dengan menggunakan metode proportionate stratified random sampling dapat diketahui jumlah sampel penelitian sebagai responden adalah sebanyak 70 orang karyawan PT. Tirta Investama di Mambal, Badung. Penentuan responden yang dijadikan sebagai sampel diharapkan memenuhi unsur keadilan, sehingga responden pada masing-masing bagian dipilih dari berbagai karakteristik umur, jenis kelamin, dan pendidikan terakhir.

Metode pengumpulan data yang digunakan dalam penelitian ini adalah sebagai berikut. Observasi, yaitu metode pengumpulan data dengan mengadakan pengamatan secara langsung tentang obyek yang diteliti dan mencatat data yang diperlukan sesuai dengan pembahasan, seperti aktivitas kerja karyawan. Wawancara, yaitu metode pengumpulan data dengan cara berkomunikasi langsung dengan cara melakukan tanya jawab langsung baik dengan kepala departemen dan karyawan PT. Tirta Investama Mambal, Badung untuk mendapatkan informasi awal tentang kepuasan kerja karyawan, gaya kepemimpinan transformasional, budaya organisasi, program keselamatan dan kesehatan kerja. Kuesioner, yaitu teknik pengumpulan data dengan menggunakan daftar pertanyaan tentang variabel kepuasan kerja karyawan, gaya kepemimpinan transformasional, budaya organisasi, program keselamatan dan kesehatan kerja yang disebarkan kepada responden yaitu karyawan PT. Tirta Investama Mambal, 
Badung. Kuesioner yang digunakan adalah tipe pilihan, dimana responden diberikan alternatif jawaban untuk memilih satu dari lima jawaban yang telah disediakan.

Sumber data yang digunakan dari penelitian ini adalah penarikan data primer yang menggunakan kuesioner, maka data yang diperoleh bersifat kualitatif. Data tersebut dikuantitatifkan dengan cara memberikan skor pada masing-masing jawaban responden. Skala pengukuran yang digunakan dalam penelitian ini adalah skala Likert. Menurut Riduwan \& Sunarto (2012:29) skala Likert yaitu skala yang digunakan untuk mengukur sikap, pendapat, dan persepsi seseorang atau sekelompok orang tentang fenomena sosial. Setiap jawaban kuesioner mempunyai bobot atau skor nilai dengan skala Likert sebagai berikut. Sangat Tidak Setuju (STS) diberi skor 1, Tidak Setuju (TS) diberi skor 2, CukupSetuju (CS) diberi skor 3, Setuju (S) diberi skor 4, Sangat Setuju (SS) diberi skor 5.

\section{HASIL DAN PEMBAHASAN}

Suatu instrumen dikatakan valid dan sah apabila memiliki koefisien korelasi pearson product moment $(\mathrm{r})>\mathrm{r}$ tabel $=0,3$. Hasil Uji Validitas Instrumen Penelitian dapat dilihat pada Tabel 1. adalah sebagai berikut.

Tabel 1.

Hasil Uji Validitas Instrumen Penelitian

\begin{tabular}{lcccc}
\hline No. $\quad$ Variabel & $\begin{array}{c}\text { Item } \\
\text { Pertanyaan }\end{array}$ & $\begin{array}{c}\text { Koefisien } \\
\text { Korelasi }\end{array}$ & $\begin{array}{c}\text { Validitas } \\
\text { Syarat } \\
\text { Valid }\end{array}$ & Keterangan \\
\hline & $\mathrm{X}_{1.1}$ & 0,671 & 0,3 & Valid \\
1. Gaya Kepemimpinan & $\mathrm{X}_{1.2}$ & 0,682 & 0,3 & Valid \\
Transformasional $\left(\mathrm{X}_{1}\right)$ & $\mathrm{X}_{1.3}$ & 0,682 & 0,3 & Valid \\
& $\mathrm{X}_{1.4}$ & 0,641 & 0,3 & Valid \\
& $\mathrm{X}_{1.5}$ & 0,782 & 0,3 & Valid \\
\hline & $\mathrm{X}_{2.1}$ & 0,652 & 0,3 & Valid \\
& $\mathrm{X}_{2.2}$ & 0,753 & 0,3 & Valid \\
2. & $\mathrm{X}_{2.3}$ & 0,867 & 0,3 & Valid \\
& $\mathrm{X}_{2.4}$ & 0,816 & 0,3 & Valid \\
& $\mathrm{X}_{2.5}$ & 0,811 & 0,3 & Valid \\
\hline & $\mathrm{X}_{3.1}$ & 0,608 & 0,3 & Valid \\
& $\mathrm{X}_{3.2}$ & 0,624 & 0,3 & Valid \\
3. Program Keselamatan dan & $\mathrm{X}_{3.3}$ & 0,778 & 0,3 & Valid \\
& $\mathrm{X}_{3.4}$ & 0,771 & 0,3 & Valid \\
& $\mathrm{X}_{3,5}$ & 0,759 & 0,3 & Valid \\
\hline & $\mathrm{Y}_{1}$ & 0,790 & 0,3 & Valid \\
& $\mathrm{Y}_{2}$ & 0,807 & 0,3 & Valid \\
& $\mathrm{Y}_{3}$ & 0,824 & 0,3 & Valid \\
& $\mathrm{Y}_{4}$ & 0,671 & 0,3 & Valid \\
& $\mathrm{Y}_{5}$ & 0,812 & 0,3 & Valid \\
\hline
\end{tabular}

Sumber: Data Diolah, 2020

Berdasarkan Tabel 1. menunjukkan bahwa instrumen penelitian variabel Gaya Kepemimpinan Transformasional $\left(\mathrm{X}_{1}\right)$, Budaya Organisasi $\left(\mathrm{X}_{2}\right)$, Program Keselamatan dan Kesehatan Kerja $\left(\mathrm{X}_{3}\right)$ dan Kepuasan Kerja Karyawan (Y) 
seluruhnya adalah valid. Dikatakan valid karena semua instrumen penelitian memiliki koefisien korelasi pearson product moment $(\mathrm{r})>r$ tabel $=0,3$. Hal ini berarti instrumen penelitian yang digunakan adalah sah yaitu pernyataanpernyataan pada kuisioner mampu mengungkapkan apa yang diukur oleh kuisioner tersebut.

Ketentuan suatu instrumen dikatakan reliable atau handal, apabila memiliki koefisien cronbach's alpha $(\alpha)$ lebih besar dari 0,60. Hasil uji reliabilitas instrumen penelitian dapat dilihat pada Tabel 2. adalah sebagai berikut.

Tabel 2.

Hasil Uji Reliabilitas Instrumen Penelitian

\begin{tabular}{lccc}
\hline \multicolumn{1}{c}{ Variabel } & $\begin{array}{c}\text { Cronbach's } \\
\text { Alpha }\end{array}$ & $\begin{array}{c}\text { Reliabilitas } \\
\text { Syarat } \\
\text { Reliable }\end{array}$ & Keterangan \\
\hline Gaya Kepemimpinan & 0,726 & 0,60 & Reliable \\
Transformasional $\left(\mathrm{X}_{1}\right)$ & 0,840 & 0,60 & Reliable \\
Budaya Organisasi $\left(\mathrm{X}_{2}\right)$ & 0,756 & 0,60 & Reliable \\
Program Keselamatan dan Kesehatan & 0,840 & 0,60 & Reliable \\
Kerja (X) & & & \\
Kepuasan Kerja Karyawan (Y) & & &
\end{tabular}

Berdasarkan Tabel 2. menunjukkan bahwa instrumen penelitian variabel Gaya Kepemimpinan Transformasional $\left(\mathrm{X}_{1}\right)$, Budaya Organisasi $\left(\mathrm{X}_{2}\right)$, Program Keselamatan dan Kesehatan Kerja $\left(\mathrm{X}_{3}\right)$ dan Kepuasan Kerja Karyawan (Y) seluruhnya adalah reliable. Dikatakan reliable karena semua instrumen penelitian memiliki koefisien cronbach's alpha $(\alpha)$ lebih besar dari 0,60. Hal ini berarti seluruh instrumen penelitian adalah reliable atau handal karena jawaban tiap responden dianggap konsisten atau stabil dari waktu ke waktu.

Hasil uji validitas dan reliabilitas instrumen penelitian menunjukkan seluruhnya adalah valid dan reliable sehingga seluruh instrumen dapat digunakan dalam analisis.

Penelitian dilakukan dengan menyebarkan kuisioner kepada 70 orang karyawan di PT. Tirta Investama Mambal, Badung yang dijadikan sebagai responden. Variabel Gaya Kepemimpinan Transformasional memiliki 5 pernyataan, variabel Budaya Organisasi memiliki 5 pernyataan, variabel Program Keselamatan dan Kesehatan Kerja memiliki 5 pernyataan dan variabel Kepuasan Kerja Karyawan memiliki 5 pernyataan.

Analisis statistik deskriptif adalah statistik yang digunakan untuk menganalisis data dengan cara mendeskripsikan atau menggambarkan data yang telah terkumpul sebagaimana adanya tanpa bermaksud membuat kesimpulan yang berlaku untuk umum atau generalisasi. Uji deskriptif pada penelitian ini antara lain adalah: Karakteritik responden berdasarkan jenis kelamin, umur, pendidikan dan masa kerja dan karakteristik jawaban kuesioner dari masing-masing variabel. Karakteristik responden dalam penelitian ini dapat dilihat pada Tabel 3. Berikut. 
Tabel 3.

Karakteristik Responden

\begin{tabular}{|c|c|c|c|c|}
\hline No & Karakteristik & & Jumlah (Orang) & Persentase (\%) \\
\hline \multirow[t]{5}{*}{1} & Umur & $20-25$ tahun & 21 & $30 \%$ \\
\hline & & 26-30 tahun & 38 & $54,3 \%$ \\
\hline & & 31-35 tahun & 7 & $10 \%$ \\
\hline & & $>35$ tahun & 4 & $5,7 \%$ \\
\hline & & Total & 70 & 100.00 \\
\hline \multirow[t]{3}{*}{2} & Jenis Kemlamin & Laki-Laki & 46 & 65,7 \\
\hline & & Perempuan & 24 & 34,3 \\
\hline & & Total & 70 & 100.00 \\
\hline \multirow[t]{4}{*}{3} & Pendidikan & $\mathrm{SMA} / \mathrm{K}$ & 30 & $42,9 \%$ \\
\hline & & Diploma & 32 & $45,7 \%$ \\
\hline & & Sarjana & 8 & $11,4 \%$ \\
\hline & & Total & 70 & 100.00 \\
\hline
\end{tabular}

Sumber: Data Diolah, 2020

Berdasarkan Tabel 3. diketahui bahwa dari 70 responden terdapat 21 orang (30\%) memiliki usia 20-25 tahun, 38 orang (54,3\%) memiliki usia 26-30 tahun, 7 orang (10\%) memiliki usia 31-35 tahun dan 4 orang $(5,7 \%)$ memiliki usia $>35$ tahun. Keadaan ini menunjukkan bahwa mayoritas responden di PT. Tirta Investama Mambal, Badung adalah berusia 26-30 tahun. Sedangkan berdasarkan jenis kelamin diketahui bahwa dari 70 responden terdapat 46 orang $(65,7 \%)$ berjenis kelamin laki-laki dan 24 orang $(34,5 \%)$ berjenis kelamin perempuan. Keadaan ini menunjukkan bahwa responden yang diambil berdasarkan jenis kelamin di PT. Tirta Investama Mambal, Badung adalah berjenis kelamin lakilaki. Berdasarkan pendidikan terakhir diketahui bahwa dari 70 responden terdapat 30 orang $(42,9 \%)$ yang berpendidikan SMA/K, 32 orang $(45,7 \%)$ yang berpendidikan Diploma dan 8 orang $(11,4 \%)$ yang berpendidikan Sarjana. Keadaan ini menunjukkan bahwa mayoritas responden di PT. Tirta Investama Mambal, Badung adalah berpendidikan diploma.

Tabel 4.

Hasil Uji Normalitas

\begin{tabular}{llr}
\hline One-Sample Kolmogorov-Smirnov Test & & Unstandardized Residual \\
\hline $\mathrm{N}$ & & 70 \\
Normal Parameters ${ }^{\mathrm{a}, \mathrm{b}}$ & Mean & .0000000 \\
& Std. Deviation & .94828858 \\
Most Extreme Differences & Absolute & .073 \\
& Positive & .073 \\
Test Statistic & Negative & -.058 \\
Asymp. Sig. (2-tailed) & & .073 \\
Sumber: Data Diolah, 2020 & & $.200^{\mathrm{c}, \mathrm{d}}$ \\
\hline
\end{tabular}


Uji normalitas data bertujuan untuk menguji apakah dalam model regresi, variabel residual memiliki distribusi normal (Ghozali, 2013). Berdasarkan tabel 4. diperoleh nilai Asymp. Sig. (2-tailed) sebesar 0,200. Karena nilai signifikansinya lebih dari 0,05 maka distribusi dari model regresi adalah normal. Pengujian normalitas data menggunakan Test of Normality Kolmogorov-Smirnov menggunakan program SPSS 24.0 for Windows dapat di lihat pada Tabel 4.

Asumsi multikolinieritas menyatakan bahwa dalam regresi berganda gejala korelasi antar variable bebas seharusnya tidak ada. Untuk mengetahui suatu model regresi bebas dari multikolinearitas, salah satu caranya dengan melihat nilai VIF (Variance Inflasion Factor) $<10$ dan angka Tolerance $>0,1$ maka dinyatakan tidak ada multikolinearitas. Nilai Tolerance dan VIF dapat dilihat pada Tabel 5. adalah sebagai berikut.

Tabel 5.

Hasil Uji Multikolinearitas

\begin{tabular}{|c|c|c|c|}
\hline \multirow{2}{*}{ Variabel } & \multicolumn{2}{|c|}{ Collinearity Statistics } & \multirow{2}{*}{ Keterangan } \\
\hline & Tolerance & VIF & \\
\hline $\begin{array}{l}\text { Gaya Kepemimpinan } \\
\text { Transformasional (X1) }\end{array}$ & 0,446 & 2,240 & Non Multikolinieritas \\
\hline Budaya Organisasi (X2) & 0,314 & 3,184 & Non Multikolinieritas \\
\hline $\begin{array}{l}\text { Program Keselamatan dan Kesehatan } \\
\text { Kerja (X3) }\end{array}$ & 0,360 & 2,776 & Non Multikolinieritas \\
\hline
\end{tabular}

Sumber: Data Diolah, 2020

Berdasarkan hasil Tabel 5. tersebut dapat dilihat bahwa nilai tolerance masing-masing variabel lebih besar dari 0,10 dan nilai VIF lebih kecil dari 10, maka dapat disimpulkan tidak terjadi multikolinearitas atau tidak terjadi korelasi diantara variabel Gaya Kepemimpinan Transformasional, Budaya Organisasi dan Program Keselamatan dan Kesehatan Kerja.

Hasil uji heteroskedastisitas dengan uji glejser diperoleh dengan menggunakan program SPSS 24.0 for Windows dapat di lihat pada tabel 6. adalah sebagai berikut.

Tabel 6.

Hasil Uji heteroskedastisitas

\begin{tabular}{|c|c|c|c|c|c|c|}
\hline \multicolumn{7}{|l|}{ Coefficients $^{\mathrm{a}}$} \\
\hline \multirow[b]{2}{*}{ Model } & & \multicolumn{2}{|c|}{$\begin{array}{l}\text { Unstandardized } \\
\text { Coefficients }\end{array}$} & \multicolumn{2}{|c|}{$\begin{array}{l}\text { Standardized } \\
\text { Coefficients }\end{array}$} & \multirow[b]{2}{*}{ Sig. } \\
\hline & & B & Std. Error & Beta & $\mathbf{t}$ & \\
\hline \multirow[t]{4}{*}{1} & (Constant) & 1.646 & 1.412 & & 1.165 & .248 \\
\hline & $\mathrm{X} 1$ & .003 & .089 & .007 & .039 & .969 \\
\hline & $\mathrm{X} 2$ & .150 & .095 & .339 & 1.584 & .118 \\
\hline & $\mathrm{X} 3$ & -.184 & .101 & -.362 & -1.813 & .074 \\
\hline
\end{tabular}

Sumber: Data Diolah, 2020

Uji heteroskedastisitas bertujuan untuk menguji apakah dalam model regresi terjadi ketidaksamaan variance dari residual antara satu pengamatan dengan pengamatan lainnya. Mendeteksi ada atau tidak heteroskedastisitas dilakukan dengan uji Glejser, mengusulkan untuk meregresi nilai absolut residual terhadap 
variabel independen. Variabel independen diketahui signifikan secara statistik mempengaruhi variabel dependen, maka ada indikasi terjadi heteroskedastisitas. Ketentuan tidak mengandung adanya heteroskedastisitas diketahui jika probabilitas signifikansinya lebih dari 0,05 .

Berdasarkan tabel 6. diperoleh bahwa nilai probabilitas signifikansi untuk masing-masing variabel memiliki nilai sebesar 0,969, 0,118, 0,074. Ini berarti bahwa nilai signifikansinya lebih dari 0,05 , maka dapat disimpulkan bahwa tidak terjadi heteroskedastisitas.

Berdasarkan hasil uji asumsi klasik maka diketahui pada persamaan regresi bahwa distribusi data adalah normal, tidak terjadi gejala multikolinearitas, dan tidak terjadi gejala heteroskedastisitas sehingga model regresi bisa digunakan karena mendapatkan hasil prediksi yang baik atau bisa bisa memberikan manfaat dengan benar.

Adapun hasil analisis regresi linier berganda disajikan pada Tabel 7. adalah sebagai berikut.

Tabel 7.

Hasil uji Regeresi Linier Berganda

\begin{tabular}{|c|c|c|c|c|c|c|}
\hline \multirow[b]{2}{*}{ Model } & & \multicolumn{2}{|c|}{$\begin{array}{l}\text { Unstandardized } \\
\text { Coefficients }\end{array}$} & \multicolumn{2}{|l|}{$\begin{array}{c}\text { Standardized } \\
\text { Coefficients }\end{array}$} & \multirow[b]{2}{*}{ Sig. } \\
\hline & & B & Std. Error & Beta & 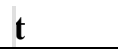 & \\
\hline \multirow[t]{4}{*}{1} & (Constant) & -2.197 & 1.281 & & -1.714 & .091 \\
\hline & $\mathrm{X} 1$ & .286 & .081 & .256 & 3.544 & .001 \\
\hline & $\mathrm{X} 2$ & .260 & .086 & .261 & 3.025 & .004 \\
\hline & $\mathrm{X} 3$ & .563 & .092 & .493 & 6.125 & .000 \\
\hline
\end{tabular}

Sumber: Data Diolah, 2020

Berdasarkan Tabel 7. diperoleh persamaan garis regresi linier antara Gaya Kepemimpinan Transformasional, Budaya Organisasi dan Program Keselamatan dan Kesehatan Kerja secara simultan terhadap Kepuasan Kerja Karyawan adalah sebagai berikut.

$$
Y=-2,197+0,286 X_{1}+0,260 X_{2}+0,563 X_{3}+e
$$

Berdasarkan nilai $\alpha, b_{1}, b_{2}, b_{3}$ diperoleh persamaan garis regresi linier berganda antara Gaya Kepemimpinan Transformasional, Budaya Organisasi dan Program Keselamatan dan Kesehatan Kerja terhadap Kepuasan Kerja Karyawan memberikan informasi bahwa: a $=-2,197$, nilai konstanta negatif menunjukan apabila tidak ada perhatian terhadap Gaya Kepemimpinan Transformasional $\left(\mathrm{X}_{1}\right)$, Budaya Organisasi $\left(\mathrm{X}_{2}\right)$ dan Program Keselamatan dan Kesehatan Kerja $\left(\mathrm{X}_{3}\right)$ atau nilainya adalah nol maka skor Kepuasan Kerja Karyawan akan turun sebesar 2,197. $b_{1}=0,286$, artinya apabila Budaya Organisasi $\left(\mathrm{X}_{2}\right)$ dan Program Keselamatan dan Kesehatan Kerja $\left(\mathrm{X}_{3}\right)$ dianggap konstan maka meningkatnya skor Gaya Kepemimpinan Transformasional $\left(\mathrm{X}_{1}\right)$ akan diikuti oleh meningkatnya skor Kepuasan Kerja Karyawan (Y) rata-rata sebesar 0,286. $\mathrm{b}_{2}=0,260$, artinya apabila Gaya Kepemimpinan Transformasional $\left(\mathrm{X}_{1}\right)$ dan Program Keselamatan dan Kesehatan Kerja $\left(\mathrm{X}_{3}\right)$ dianggap konstan maka meningkatnya skor Budaya Organisasi $\left(\mathrm{X}_{2}\right)$ akan diikuti oleh meningkatnyannya skor Kepuasan Kerja 
Karyawan (Y) rata-rata sebesar $0,260 . \mathrm{b}_{3}=0,563$, artinya apabila Gaya Kepemimpinan Transformasional $\left(\mathrm{X}_{1}\right)$ dan Budaya Organisasi $\left(\mathrm{X}_{2}\right)$ dianggap konstan maka meningkatnya skor Program Keselamatan dan Kesehatan Kerja ( $\left.\mathrm{X}_{3}\right)$ akan diikuti oleh meningkatnya skor Kepuasan Kerja Karyawan (Y) rata-rata sebesar 0,563.

Analisis korelasi berganda digunakan untuk mengetahui derajat atau kekuatan hubungan antara seluruh variabel $\mathrm{X}$ terhadap variabel $\mathrm{Y}$ secara bersamaan. Hasil analisis korelasi berganda dapat dilihat pada Tabel 8. adalah sebagai berikut.

Tabel 8.

Hasil Koefisien Korelasi Berganda

\begin{tabular}{lllllllll}
\hline & \multicolumn{9}{c}{$\begin{array}{c}\text { Std. Error } \\
\text { of the } \\
\text { Model R }\end{array}$} & $\begin{array}{c}\text { Change Statistics } \\
\text { Square }\end{array}$ & $\begin{array}{l}\text { Ch Square } \\
\text { Square }\end{array}$ & $\begin{array}{l}\text { Estimate } \\
\text { Change }\end{array}$ & F Change & df1 & df2 & $\begin{array}{c}\text { Sig. F } \\
\text { Change }\end{array}$ \\
\hline $1 \quad .920^{\mathrm{a}}$ & .846 & .839 & .970 & .846 & 120.782 & 3 & 66 & .000 \\
\hline Sumber: Data Diolah, 2020 & & & & & &
\end{tabular}

Berdasarkan Tabel 8. diperoleh hasil koefisien korelasi berganda (R) sebesar 0,920 . Karena nilai $\mathrm{R}=0,920$ maka hubungan yang ada adalah hubungan yang sangat kuat. Ini berarti bahwa secara bersama-sama (simultan) terdapat hubungan yang sangat kuat antara Gaya Kepemimpinan Transformasional, Budaya Organisasi dan Program Keselamatan dan Kesehatan Kerja terhadap Kepuasan Kerja Karyawan.

Berdasarkan Tabel 8. diketahui bahwa nilai $\mathrm{R}^{2}=84,6 \%$, artinya sebesar 84,6\% Kepuasan Kerja Karyawan dipengaruhi oleh variabel Gaya Kepemimpinan Transformasional, Budaya Organisasi dan Program Keselamatan dan Kesehatan Kerja sedangkan sisanya sebesar 15,4\% (100\%-84,6\%) dipengaruhi oleh variabel lain yang tidak dianalisis dalam penelitian ini.

Untuk membuktikan apakah Gaya Kepemimpinan Transformasional, Budaya Organisasi dan Program Keselamatan dan Kesehatan Kerja memang benar atau secara kebetulan mempengaruhi Kepuasan Kerja Karyawan online tiket pesawat dengan mengguanakan situs Traveloka maka akan diuji dengan menggunakan Uji F dan Uji t.

Berdasarkan hasil olah data dengan menggunakan program SPSS 24.0 for windows, dapat dilihat pada tabel 8. menunjukan F-hitung sebesar 120,782 dengan signifikansi 0,000 (dapat dilihat pada lampiran hasil uji hipotesis pada tabel ANOVA). Karena tingkat signifikasi kurang dari 0,05 maka model regresi dapat digunakan untuk memprediksi Gaya Kepemimpinan Transformasional (X1), Budaya Organisasi (X2) dan Program Keselamatan dan Kesehatan Kerja (X3) secara simultan berpengaruh signifikan terhadap Kepuasan Kerja Karyawan (Y).

Uji $t$ digunakan untuk menguji signifikansi masing-masing koefisien regresi $b_{1}, b_{2}$, dan $b_{3}$ sehingga diketahui apakah secara individual pengaruh antara Gaya Kepemimpinan Transformasional (X1), Budaya Organisasi (X2) dan Program Keselamatan dan Kesehatan Kerja (X3) terhadap Kepuasan Kerja Karyawan (Y) adalah memang nyata terjadi (signifikan) atau hanya diperoleh secara kebetulan.

Berdasarkan olah data menggunakan program SPSS 24.0 for windows, dapat dilihat hasil uji pada tabel 7 . menunjukan $\mathrm{t}_{1}$-hitung sebesar 3,544 dengan 
signifikansi 0,001 . Sesuai hasil perhitungan maka diperoleh $t_{\mathrm{h} 1}$ adalah 3,544 lebih dari t-tabel 2,00 berada pada daerah penolakan $\mathrm{H}_{0}$ maka Gaya Kepemimpinan Transformasional berpengaruh positif dan signifikan terhadap Kepuasan Kerja Karyawan dan tidak diperoleh secara kebetulan.

Berdasarkan olah data menggunakan program SPSS 24.0 for windows, dapat dilihat hasil uji pada table 7. menunjukan t-hitung sebesar 3,025 dengan signifikansi 0,004. Sesuai hasil perhitungan maka diperoleh $t_{\mathrm{h} 2}$ adalah 3,025 lebih dari t-tabel 2,00 berada pada daerah penolakan $\mathrm{H}_{0}$ maka Budaya Organisasi berpengaruh positif dan signifikan terhadap Kepuasan Kerja Karyawan dan tidak diperoleh secara kebetulan.

Berdasarkan olah data menggunakan program SPSS 24.0 for windows, dapat dilihat hasil uji pada table 7. menunjukan t-hitung sebesar 6,125 dengan signifikansi 0,000. Sesuai hasil perhitungan maka diperoleh $\mathrm{t}_{\mathrm{h} 3}$ adalah 6,125 lebih dari t-tabel 2,00 berada pada daerah penolakan $\mathrm{H}_{0}$ maka Program Keselamatan dan Kesehatan Kerja berpengaruh positif dan signifikan terhadap Kepuasan Kerja Karyawan dan tidak diperoleh secara kebetulan.

Penelitian ini telah mampu menjelaskan model teori tentang nilai-nilai yang terkandung dalam gaya kepemimpinan transformasional, budaya organsisasi dan program kesehatan dan keselamatan kerja dalam mempengaruhi kepuasan kerja. Hasil model teoritis tersebut menjelaskan bahwa nilai-nilai yang terkandung dalam gaya kepemimpinan transformasional, budaya organsisasi dan program kesehatan dan keselamatan kerja secara langsung mempengaruhi kepuasan kerja. Penelitian ini menegaskan konsep gaya kepemimpinan transformasional, budaya organsisasi dan program kesehatan dan keselamatan kerja berpengaruh positif terhadap kepuasan kerja. Hasil penelitian ini mengungkapkan pentingnya pihak manajemen memperhatikan seberapa besar gaya kepemimpinan transformasional, budaya organsisasi dan program kesehatan dan keselamatan kerja mempengaruhi tingkat kepuasan kerja.

Pada uji parsial ditemukan bahwa gaya kepemimpinan transformasional berpengaruh secara positif dan signifikan terhadap kepuasan kerja. Ini berarti bahwa gaya kepemimpinan transformasional yang ada di PT. Tirta Investama Mambal, Badung mampu memberikan peningkatan kepuasan kerja. Budaya organsisasi berpengaruh positif dan signifikan terhadap kepuasan kerja pada PT. Tirta Investama Mambal, Badung. Ini berarti bahwa budaya organsisasi yang ada di PT. Tirta Investama Mambal, Badung mampu memberikan peningkatan kepuasan kerja. Program kesehatan dan keselamatan kerja berpengaruh positif dan signifikan terhadap kepuasan kerja pada PT. Tirta Investama Mambal, Badung. Hasil tersebut memiliki arti bahwa semakin tinggi Program kesehatan dan keselamatan kerja yang dirasakan karyawan maka akan meningkatkan kepuasan kerja dan sebaliknya apabila program kesehatan dan keselamatan kerja yang dirasakan rendah maka akan menurunkan kepuasan kerja tersebut.

\section{SIMPULAN}

Berdasarkan hasil analisis data dan pembahasan yang telah dilakukan, maka dapat ditarik simpulan hasil penelitian yaitu sebagai berikut. Gaya Kepemimpinan 
Transformasional (X1) berpengaruh positif dan signifikan terhadap Kepuasan Kerja Karyawan di PT. Tirta Investama Mambal, Badung. Hasil ini menunjukkan bahwa apabila gaya kepemimpinan transformasional semakin baik maka akan meningkatkan kepuasan kerja. Budaya Organisasi (X2) berpengaruh positif dan signifikan terhadap Kepuasan Kerja Karyawan di PT. Tirta Investama Mambal, Badung. Hasil ini menunjukkan bahwa semakin tinggi budaya organisasi maka akan meningkatkan kepuasan kerja.Program Keselamatan dan Kesehatan Kerja (X3) berpengaruh positif dan signifikan terhadap Kepuasan Kerja Karyawan di PT. Tirta Investama Mambal, Badung. Hasil ini menunjukkan bahwa semakin tinggi program keselamatan dan kesehatan kerja maka akan meningkatkan kepuasan kerja.

Berdasarkan hasil analisis, pembahasan, dan simpulan, maka saran yang dapat diberikan adalah manajemen PT Tirta Investama Mambal Badung perlu meningkatkan komunikasi langsung dengan menekankan pentingnya nilai-nilai organisasi untuk mencapai tujuan. Peningkatan terhadap sikap ini dapat meningkatkan kepuasan kerja pada PT Tirta Investama Mambal Badung. Sedangkan pihak PT Tirta Investama Mambal Badung perlu menguasai pekerjaan dengan baik dan bekerja sesuai arahan supervisi dengan berorientasi pada hasil yang dicapai. Peningkatan terhadap sikap ini dapat meningkatkan kepuasan kerja pada PT Tirta Investama Mambal Badung. Manajemen PT Tirta Investama Mambal Badung juga perlu menggunakan peralatan dan fasilitas teknik yang memadai sehingga dapat menjalankan proses kerja dengan baik. Peningkatan terhadap sikap ini dapat meningkatkan kepuasan kerja pada PT Tirta Investama Mambal Badung.

\section{REFERENSI}

Anatan, Lina dan Lena, Allitan. (2008). Manajemen Sumber Daya Manusia Dalam Bisnis Modern. Bandung: Alfabeta.

Ardana, I. K., Mudiartha, U. dan Mujiati, W. (2012). Manajemen Sumber Daya Manusia. Denpasar: UPT Penerbit Universitas Udayana.

Arishanti, Klara Innata. (2009). Pengaruh Budaya Organisasi dan Komitmen Organisasional Terhadap Kepuasan Kerja Karyawan. Jurnal Proceeding PESAT (Psikologi, Ekonomi, Sastra, Arsitektur, dan Sipil), 3, 44-52.

Bushra, F. (2011). Effect of Transformational Leadership on Employees' Job Satisfaction and Organizational Commitment in Banking Sector of Lahore (Pakistan). International Journal of Business and Social Science, 2(18), 261-267.

Estiawan, Firman Syahifudin. (2012). Analisis Sistem Manajemen Keselamatan dan Kesehatan Kerja (SMK3) Terhadap Kepuasan Kerja Karyawan, Studi pada PT PJB. UP Brantas (Perusahaan yang Bergerak pada Bidang Pemeliharaan dan Pembangkitan Listrik). Jurnal Fakultas Ekonomi dan Bisnis, Universitas Brawijaya Malang, 1-17. 
I Gusti Ngurah Aritama Negara, Pengaruh Gaya Kepemimpinan...

Ghozali, I. (2013). Aplikasi Analisis Multivariate dengan Program SPSS. Semarang: Badan Penerbit Universitas Diponegoro.

Gunawan, Ketut. (2010). Pembuktian Budaya Organisasi Pada Kepuasan Kerja. Jurnal Akuntansi, Manajemen Bisnis dan Sektor Publik (JAMBSP), 6(3), 285-297.

Gupta, Anu. (2012). Impact of Occupational Health Safety on Employee Satisfaction. International Journal of Scientific Research, 1(7), 118-120.

Gupta, Shobhna. (2013). A Comparative Study of Job Satisfaction in Public and Private Sector. Indian Journal of Arts, 1(1), 235-242.

Jogiyanto, H. M. (2011). Metodologi Penelitian Bisnis: Salah Kaprah dan Pengalaman-Pengalaman. Yogyakarta: BPFE.

Kurniawan, I. (2011). Pengaruh Keselamatan dan Kesehatan Kerja Terhadap Kepuasan Kerja Karyawan (Studi pada Karyawan Bagian Produksi PT Indohamafish Jembrana Bali). Jurnal Fakultas Ilmu Administrasi Universitas Brawijaya Malang, 1-11.

Luthans, Fred. (2008). Perilaku Organisasi. Edisi Kesepuluh. Yogyakarta: Andi.

Mangkunegara, Anwar Prabu. (2010). Perilaku dan Budaya Organisasi. Bandung: PT Refika Aditama.

Mathis, R. L. dan Jhon, H. J. (2010). Manajemen Sumber Daya Manusia. Buku I. Jakarta: Salemba Empat.

Mulyono, Sri. (2008). Statistika Untuk Ekonomi dan Bisnis. Jakarta: Lembaga Penerbit Fakultas Ekonomi Universitas Indonesia.

MacIntosh, E. (2009). The influence of Organizational Culture on Job Satisfaction and Intention to Leave. Journal of Sport Management Review, 13, 106-117.

Maqsood, S. (2013). Manager's Leadership Styles and Employee's Job Satisfaction. Journal of Human and Social Science Research, 1(2), 139-144.

Mehr, S. K. (2012). Relationship Between Job Satisfaction and Organizational Culture in Staffs and Experts of Physical Education Offices of Mazandaran Province. European Journal of Experimental Biology, 2(4), 1029-1033.

Nafrizal. (2012). Pengaruh Insentif, Motivasi Kerja, Gaya Kepemimpinan dan Budaya Organisasi Terhadap Kepuasan Kerja Serta Dampaknya pada Kinerja Personil Polri pada Satuan Kerja Biro Operasi Mapolda Aceh. Jurnal Manajemen Pascasarjana Universitas Syiah Kuala, 2(1), 52-67. 
Purnama, C. (2013). Influence Analysis of Organizational Culture Organizational Commitment Job and Satisfaction Organizational Citizenship Behavior (OCB) Toward Improved Organizational Performance. International Journal of Business, Humanities and Technology, 3(5), 86-100.

Purnomo, Heru dan Muhammad, Cholil. (2010). Pengaruh Gaya Kepemimpinan Terhadap Kepuasan Kerja Berdasarkan Motivasi Kerja pada Karyawan Administratif di Universitas Sebelas Maret Surakarta. Jurnal Manajemen Sumberdaya Manusia, 4(1), 27-35.

Rahim, Hesti Aulia. (2012). Pengaruh Kesehatan dan Keselamatan Kerja (K3) Terhadap Kepuasan Kerja Karyawan Unilever (Studi pada Tea Based Beverage (TBB) Factory Unilever Indonesia di Cikarang, Bekasi). Jurnal Program Studi Manajemen Fakultas Ekonomi Universitas Bakrie, 1-3.

Riduwan, \& Sunarto. (2012). Pengantar Statistika Untuk Penelitian Pendidikan, Sosial, Ekonomi, dan Bisnis. Bandung: Alfabeta.

Rizi, R. M. (2013). Relationship Between Leadership Styles and Job Satisfaction Among Physical Education Organizations Employees. European Journal of Sports and Exercise Science, 2(1), 7-11.

Rizondra. (2013). Pengaruh Motivasi Kerja, Gaya Kepemimpinan dan Budaya Organisasi Terhadap Kinerja Pegawai Dengan Kepuasan Kerja Pegawai Sebagai Intervening Variabel pada Dipertahortnakbun Kabupaten Pesisir Selatan. Jurnal Program Studi Magister Sains Manajemen Program Pascasarjana Universitas Bung Hatta, 1-17.

Robbins, S. P., \& Timothy, A. J. (2008). Perilaku Organisasi (12th ed.). Jakarta: salemba empat.

Sageer, A. (2012). Identification of Variables Affecting Employee Satisfaction and Their Impact on the Organization. Journal of Business and Management, 5(1), 32-39.

Saputra, B. M. (2012). Pengaruh Gaya Kepemimpinan Transformasional Terhadap Kepuasan Kerja Melalui Kepercayaan Karyawan pada Atasan (Studi pada STT, STMIK, STBA dan Politeknik Cahaya Surya). Jurnal Otonomi, 13(1), 117-126.

Sedarmayanti. (2011). Manajemen Sumber Daya Manusia. Bandung: PT Refika Aditama.

Sunadji. (2013). The Role of Organizational Culture, Leadership, Communication, and Job Satisfaction on Employee Performance (Study on Public Enterprise of Water Reseorce Management of Ministry State-Owned Enterprise). International Journal of Business and Behavioral Sciences, 3(2), 34-42. 
I Gusti Ngurah Aritama Negara, Pengaruh Gaya Kepemimpinan...

Supardi, \& Anwar, S. (2011). Dasar-Dasar Perilaku Organisasi. Yogyakarta: UII Press.

Syauta, J. H. (2012). The Influence of Organizational Culture, Organizational Commitment to Job Satisfaction and Employee Performance (Study at Municipal Waterworks of Jayapura, Papua Indonesia). International Journal of Business and Management Invention, 11(1), 69-76.

Tawiah, K. A. (2011). Occupational Health and Safety: Key Issues and Concerns in Ghana. International Journal of Business and Social Science, 2(14), 119126.

Thamrin, H. M. (2012). The Influence of Transformational Leadership andOrganizational Commitment on Job Satisfaction andEmployee Performance. Jurnal International Journal of Innovation, Management and Technology, 3(5), 566-572.

Umar, H. (2011). Riset Sumber Daya Manusia Dalam Organisasi. Jakarta: PT Gramedia Pustaka Utama.

Wijanto, E. A. (2013). Pengaruh Leader Member Exchange Terhadap Kepuasan Kerja, Motivasi Kerja dan Komitmen Organisasional Karyawan Departemen Penjualan pada PT X. Jurnal Agora, 1(1), 1-10.

Yukl, G. A. (2010). Kepemimpinan Dalam Organisasi. Jakarta: Indeks.

Yuniarsih, T., \& Suwatno. (2008). Manajemen Sumber Daya Manusia Teori Aplikasi dan Isu Penelitian. Bandung: Alfabeta.

Yusnita, M. (2012). Pengaruh Program Keselamatan dan Kesehatan Kerja (K3) Terhadap Kepuasan Kerja Karyawan Bagian Produksi pada PT Keong Nusantara Abadi Natar Lampung Selatan. Jurnal Ilmiah, 5(1), 48-54. 